\title{
STUDIES ON THE BIOLOGY OF LIMPETS
}

\author{
III. HERMAPHRODITISM IN THE THREE BRITISH \\ SPECIES OF PATELLA
}

By J. M. Dodd

Gatty Marine Laboratory, University of St Andrews

(Plate I)

Sex phenomena in molluscs have been widely investigated, and the relevant literature on the subject has been reviewed by Coe (1943, I944). Coe recognizes ambisexuality (monoecism, hermaphroditism) and unisexuality (dioecism, gonochorism) and further subdivides ambisexuality into functional ambisexuality (functional hermaphroditism), consecutive sexuality, rhythmical consecutive sexuality and alternative sexuality. Of these, functional hermaphroditism is of widespread occurrence: it is encountered in all the main groups, with the exception of scaphopods and cephalopods. Of the more than 20,000 species of living gastropods approximately half are functional hermaphrodites when fully adult (Coe, I944). Limpets of the genus Patella are unisexual, though there is evidence that sex change may occur in some of the species (Orton, I920, 1928, in Patella vulgata; Bacci, 1947, in P. coerulea). Little is known with certainty of the mechanism of sex-determination in these animals, but sexuality appears to be labile since it seems that more than $90 \%$ of individuals of $P$. vulgata change sex at some stage in their life history. Aberrant sexual forms might therefore reasonably be expected to occur. In the present paper thirty hermaphrodite gonads encountered in an examination of 64,576 limpets are described and their significance in the wider context of sexual phenomena in molluscs is discussed.

The late Prof. J. H. Orton suggested this study and collected most of the hermaphrodite gonads with which it deals. I am most grateful to Dr A. J. Southward for checking Orton's records of hermaphroditism and sex-change in Patella, to Dr Margaret Lang and my wife for invaluable assistance with the histological work, and to Mr D. R. R. Burt who identified the cysts of Ophryocotyle.

\section{Material and Methods}

The series of hermaphrodite gonads described here contains examples from each of the three British species of Patella. The specimens were obtained between December 1945, and December 1948, either by the late Prof. J. H. Orton during his routine examination of populations of limpets for breeding 
data, or by myself. They were collected from widely separated stations round the British coast. All specimens were fixed in Bouin's fluid in sea water and stored in $70 \%$ alcohol. Prior to dehydration and embedding, each gonad was drawn and described in ventral surface view. The gonad was then removed from the visceral mass, divided along its longer and shorter axes into four equal parts, and the dorsal and cut surfaces of each part also drawn and described. Serial sections were cut at either 5 or $15 \mu$ thickness, and the sections stained with Mallory's triple stain or Heidenhain's haematoxylin with eosin or erythrosin orange $\mathrm{G}$ as a counterstain.

\section{Previous ReCords of HeRMAPHRODItISM}

Previous records of hermaphroditism in limpets are limited to Patella vulgata. Gemmill (I896) examined approximately 250 specimens of $P$. vulgata and obtained three hermaphrodite gonads. They were normal in size, shape and anatomical position, but their colour was mottled 'showing all shades between olive-green of ovary and the light yellow of testis'. All regions appeared fully ripe, and Gemmill stated that microscopic examination showed 'not only ripe ova and spermatozoa but also segmented ova and even ciliated freely moving embryos'. One specimen showed a patchy distribution of male and female tissue with an excess of ovarian over testicular tissue; in the second specimen, one side of the gonad was purely male, whereas the other side was female, and in the third specimen only a small patch of ovarian tissue was found. Gemmill's remarkable record of developing ova and trochophores in these gonads is quite unique: in spite of a careful search during the present work no developing eggs have been found in the gonads examined. Pelseneer (I926) found one hermaphrodite gonad in 2750 specimens examined: it came from an individual $53 \mathrm{~mm}$ in length and in describing it he says 'c'était un testicule dans lequel, entre les acini mâles il y avait des rangées rectilignes d'ovules'. Orton (I928) records that in his investigations at Plymouth he never encountered hermaphroditism of the type described by Pelseneer. M. D. Jones (I933, unpublished record) examined 3000 specimens of $P$. vulgata and found only one hermaphrodite. This specimen was $46 \mathrm{~mm}$ in length and the gonad contained mainly testicular tissue: there was a small ovarian region at the anterior end. The two areas were fairly distinct apart from a few ova deeply embedded in testicular tissue. Smith (1935) examined more than Iooo specimens of $P$. vulgata and found only one hermaphrodite. Relevant data concerning these previous records are summarized in Table I.

\section{STRUCTURE OF THE GONADS}

The structure and development of the normal limpet gonad have been described and illustrated in a previous paper (Orton, Southward \& Dodd, I956). In connexion with this work many gonads of both sexes at all stages of 
Table I. Patella vulgata: Previous Records of Hermaphroditism

\begin{tabular}{|c|c|c|c|c|c|}
\hline Author & Date & Locality & $\begin{array}{l}\text { No. of } \\
\text { specimens } \\
\text { examined }\end{array}$ & $\begin{array}{l}\text { No. of } \\
\text { herm- } \\
\text { aphrodites }\end{array}$ & $\begin{array}{c}\% \\
\text { herm- } \\
\text { aphroditism }\end{array}$ \\
\hline Gemmill & I896 & Millport & c. 250 & 3 & c. I.2 \\
\hline Pelseneer & I926 & Wimereux & 2750 & $\mathrm{I}$ & 0.036 \\
\hline Orton & I928 & Plymouth & $1000+$ & 0 & Nil \\
\hline Jones* & I933 & Aberystwyth & 3000 & I & 0.033 \\
\hline Smith & I935 & Plymouth & $1000+$ & I & $<O . I$ \\
\hline
\end{tabular}

development and depletion were sectioned and examined, and all were entirely of one sex. In both sexes the gonad lies on the ventral surface of the visceral mass and, initially, the germinal epithelium lines a flattened sac-like structure. This epithelium later becomes greatly folded and the folds, supported on trabeculae of connective tissue, penetrate the cavity and obliterate it. Gametogenesis appears to be further advanced in the dorsal regions of the gonad, i.e. those in contact with the visceral mass.

The hermaphrodite gonads are individually described in Table III (see pp. 335-8), together with the dates of collection, length of foot or shell and maximum thickness of gonad: these data are of significance when considering the relationship between the types of hermaphroditism here described and the transient hermaphroditism which may be associated with sex change.

Reference to P1. I shows that, with the exception of two specimens containing trematode parasites, the hermaphrodite gonads showed well-defined areas of testicular and ovarian tissue, with some slight intermingling in the contiguous zones. P1. I, fig. 6, illustrates a feature which was relatively frequent, viz. the presence of well developed oocytes lying in the lumen of a seminiferous tubule. In most cases these oocytes were continuous with more extensive ovarian tissue, but in a few cases they were isolated and completely surrounded by testis.

P1. I, fig. 7, shows details of a typical region lying between predominantly male and predominantly female areas. Fully developed eggs and sperms are present in close proximity, together with young oocytes and a considerable amount of undifferentiated tissue.

Most of the gonads studied showed well developed oocytes and spermatozoa. In a few cases there were undoubted signs of spawning from both ovarian and testicular regions. From one hermaphrodite gonad a successful artificial fertilization was made between eggs and sperms, and apparently normal trochophores were obtained (cf. Dodd, I956).

The relative volumes of ovarian and testicular tissue in each individual hermaphrodite gonad were estimated approximately. Of the twenty-six gonads 
available for histological study, fifteen were predominantly male, nine predominantly female, and in two of them the two types of tissue were of approximately equal volume.

\section{INCIDENCE OF HERMAPHRODITISM}

When considering the incidence of hermaphroditism encountered in the present study it is important to note that Orton's examination of the gonad was limited to size and general appearance of the ventral surface. Orton was

\section{Table II. Hermaphroditism in British Species of Patella: INCIDENCE AT DIFFERENT LOCALITIES}

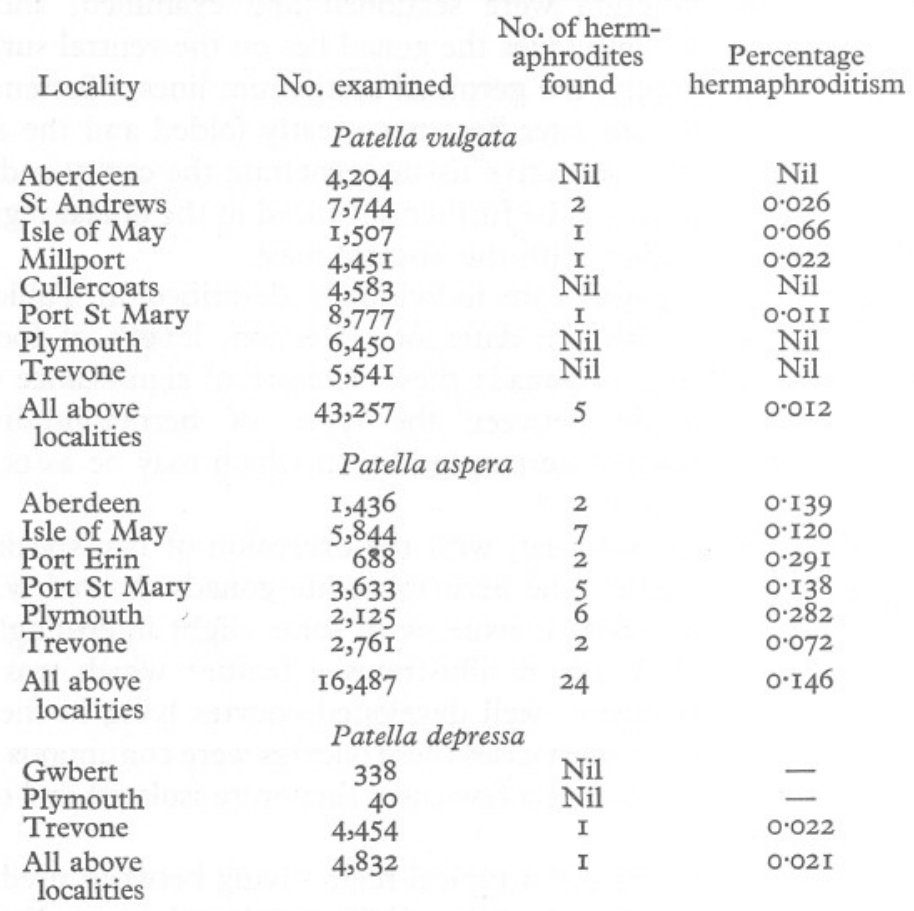

mainly interested in establishing details of the breeding cycle. As he recognized, such an examination might well result in failure to identify hermaphrodite gonads in which the ventral surface was largely or entirely of one sex, e.g. specimen B I3, Table III. However, the 5844 specimens of $P$. aspera from the Isle of May, studied by the present author, were specifically examined for signs of hermaphroditism, and it is unlikely that any cases were overlooked. It is significant that the percentage frequency of hermaphroditism in this population is closely similar to the average percentage frequency for all localities. 
The overall percentage frequencies of hermaphroditism in the three species show interesting differences. Of 43,257 specimens of $P$. vulgata examined five were hermaphrodite: a percentage of $0.0 \mathrm{I} 2$; of $\mathrm{I} 6,487$ specimens of $P$. aspera, twenty-four were hermaphrodite: a percentage of 0.146 ; while in $P$. depressa only one hermaphrodite was found in 4832 specimens. It therefore appears that hermaphroditism is some ten times more common in $P$. aspera than in $P$. vulgata or $P$. depressa.

By reference to Table III it will be observed that the majority of the hermaphrodite specimens were taken during the spawning season of the particular species. This simply reflects the fact that by far the majority of the individuals examined were collected during the breeding season. It will be realized that hermaphrodite gonads can be recognized by superficial examination only when they are active.

The records suggest that hermaphroditism in $P$. vulgata may be more common in more northern localities: this, however, does not appear to be so in $P$. aspera.

\section{Hermaphroditism in Relation to Sex Change}

As has already been mentioned, a change of sex appears to take place in $P$. vulgata and $P$. coerulea. Since incomplete sex-change would necessarily result in hermaphroditism it is important to consider to what extent this phenomenon might account for the hermaphrodite gonads encountered in the present study.

Bacci (1947) has made a detailed investigation of sex-change in $P$. coerulea. In this species it appears that sex inversion is not limited to a narrow size range; very immature oocytes appear in male gonads, though this is true only of gonads which are almost completely spent: and gonads are never found in which there are well-defined male and female zones. Clearly then, in P. coerulea, although more than I5,000 specimens were examined by Bacci no hermaphrodites of the kind described in this paper were ever encountered.

Regarding $P$. vulgata, Orton (I928) has shown that most, if not all, of the individuals are male at their first sexual maturity, the suspected change of sex from male to female occurring at an age of I year or more, though more frequently within the smaller size-groups. The percentage frequencies of the two sexes approach equality in the second year-group. In the present study of some 43,000 specimens of $P$. vulgata, only $5(0.012 \%)$ hermaphrodites were found, and most of these belonged to the larger size-groups.

As regards the remaining British species, Dr A. J. Southward is at present preparing for publication some of Orton's later data on sex-change, and he informs me that these indicate a different state of affairs. In $P$. aspera, if indeed sex-change occurs at all, it is a much rarer phenomenon since $30-40 \%$ females are already present in the smallest size-groups in which all individuals show developing gonads. In $P$. depress $a$, there is strong circumstantial 
evidence that no sex-change ever occurs, $70 \%$ males being found in the size-groups in which all specimens have differentiated gonads. Evidently, therefore, sex-change is not an essential prerequisite for hermaphroditism, though in $P$. vulgata and $P$. aspera a possible connexion between the two phenomena must be borne in mind.

\section{HeRmaphroditism In Relation to PaRAsitic InFESTATION}

Although the hermaphrodite condition is itself abnormal, both male and female parts of hermaphrodite gonads were of normal histological appearance in most individuals. Moreover, evidence that functional spermatozoa and ova may both be produced within a single gonad has already been adduced. In six of the specimens examined, however, the gonads were recognizably abnormal not only through being hermaphrodite, but also in gross morphology (Pl. I, fig. 2). In three of these there was no evidence as to the cause of the abnormality, whereas in the remaining three, the possibility must be considered that parasitic infestation was responsible. In two of the three parasitized specimens rediae of Cercaria patellae Lebour were found (P1. I, fig. 8), whilst in the other several cysts of the cestode Ophryocotyle sp. were present (Pl. I, fig. 9). Rees (I934) has described the effects produced by Cercaria patellae, and her main observations concerning partial castration are in full agreement with my own. Rees, however, did not encounter hermaphroditism. The parasitized hermaphrodite gonads which I have studied were subnormal in size and contained both ova and spermatozoa indiscriminately mixed. Many of the ova showed gross degeneration, and large areas of the gonad were entirely devoid of germ cells. It should be noted that a high proportion of most populations of limpets may be parasitized by $C$. patellae and since only two parasitized hermaphrodite specimens were found in the present study the possibility must be borne in mind that these specimens were already hermaphrodite when infested by the parasite, i.e. that they were not rendered hermaphrodite by the parasite.

The parasitized specimen (Pl. I, fig. 9) containing cestode cysts closely resembled the unparasitized hermaphrodites. The gonad was predominantly female and the ova were mostly large. A well-developed male area and some neuter tissue were associated with the largest cyst. There were restricted areas of neuter gonad tissue surrounding most of the other cysts: in one case the adjacent tissue, though predominantly neuter, contained early stages in spermatogenesis. However, since there were male regions not associated with the presence of cysts, this gonad also may possibly have already been hermaphrodite before infestation by the parasite. 


\section{DiscUSSION}

In order to assess the relationship between the type of hermaphroditism here described and the unisexual condition normal in limpets, two hypotheses may be considered. According to one hypothesis, since in Patella vulgata sex reversal apparently occurs in the great majority of individuals, hermaphrodite gonads may represent an arrest of developmental change during sex-reversal. Consideration has already been given to this possibility and it would appear that sex-change does not predispose the gonad towards hermaphroditism since the incidence of hermaphroditism in all three British species is low, whereas sex-change in $P$. vulgata must occur in at least $90 \%$ of individuals. It has also been noted that the gonads here described may contain fully developed eggs and sperms at one and the same time: Bacci (I947) found that this was never so in $P$. coerulea, in which he found the sexual phases to be relatively stable, sex-change apparently occurring during the resting period. Moreover, in nearly all of the cases here described, the hermaphrodite gonads were found in large individuals, i.e. those past the time at which sex-change is most commonly thought to occur.

According to a second hypothesis, since sexuality is probably labile in limpets the small percentage of hermaphroditism may well merely represent aberrant sexuality with either a genetical or an environmental basis. In this connexion, Coe (I945) states that although less than 400 of the more than I0,000 species of lamellibranchs are normally hermaphrodite, in most of the unisexual species which have been studied a small percentage of hermaphrodite individuals has been found. He states: 'Certain dominantly unisexual species may have local races or environmental modifications which are hermaphroditic. Furthermore, accidental or developmental hermaphroditism is of occasional occurrence in most of the unisexual species and unisexual individuals are sometimes found in dominantly hermaphroditic species.' A consideration of all the evidence in the present study leads irresistibly to the conclusion that we are here dealing with a similar form of accidental hermaphroditism for which no definite cause can be assigned at present. The low incidence appears to rule out the possibility that it is a factor associated with the external environment, though it has been shown that an abnormal internal environment due to the presence of cestode cysts can result in a fairly clear local action on the gonad structure. So far as concerns a possible genetical explanation of this phenomenon, Montalenti (I950) and Montalenti \& Bacci (I95I) have put forward a hypothesis that sex in Patella is determined by multiple genes. They postulate three pairs of alleles which segregate independently and can therefore produce sixty-four possible genotypes, one of which is a genetic male and one a genetic female, these two genotypes being represented by the small percentage of individuals which do not change sex. The remaining genotypes contain both male and female potentialities and any 
individual possessing one of these genotypes could, presumably, develop into a hermaphrodite. It should be noted that this genetical scheme was suggested to cover the entire genus, when it was thought that all species of Patella showed sex-change. This scheme may be considered to have less validity now that it appears that several of the species are truly gonochoristic. No doubt a formal genetical scheme could be arrived at which would cover all the known facts regarding sexuality in the genus Patella and allow for occasional hermaphroditism, though it would seem unlikely that any such scheme could account for the peculiar hermaphroditism here described. Conceivably these Patella hermaphrodites are developmental mosaics in which islands of germinal tissue originate from cells which by rare mitotic accident happen to be heteroploid. There is no case for elaborating this statement in view of the present lack of knowledge of molluscan chromosomes.

\section{SUMMARY}

In an examination of 64,576 specimens of the three British species of Patella, thirty hermaphrodites were encountered. The present paper describes the gonads of these animals, and discusses and compares the incidence of hermaphroditism in limpets from widely separated British localities. Three parasitized hermaphrodite gonads are described, and it is suggested that these were probably already hermaphrodite at the time of infestation by the parasite.

Consideration is given to the possibility that there is a causal connexion between sex-change and hermaphroditism, but such a connexion appears not to be supported by the available evidence.

The nature of this hermaphroditism is considered, and it is concluded that we are here dealing with accidental or developmental hermaphroditism for which no cause can be assigned, though it is tentatively suggested that the gonads may be developmental mosaics containing islands of heteroploid tissue. 


\section{Table III. Hermaphrodite Limpet Gonads: Tabulated Data}

\section{Specimen Date collected}

Locality

$$
\text { A I }
$$

$$
\text { 6. xi. } 48
$$$$
\text { 5. iii. } 49
$$

St Andrews

Isle of May

16. x. 48

29. x. 48

Millport

A 5
(P1. I,
fig. 6)
23. iii. 46

Port St

$$
\begin{aligned}
& \text { Maximum } \\
& \begin{array}{c}
\text { Length of thickness } \\
\text { shell or foot of gonad }
\end{array} \\
& \text { (mm) } \\
& \text { (mm) }
\end{aligned}
$$

\section{Description of gonad based on macroscopic}

appearance and examination of sections

(I) Patella vulgata

$$
\begin{gathered}
4 \mathrm{I} \cdot \mathrm{O} \\
(\text { shell) }
\end{gathered}
$$

7.0 Preir

Predominantly female. Great intermixing of the two elements though essentially a skin of testis over eggs which come to surface in centre region. Eggs and sperms appear mature, though there are a fair number of young eggs

$$
\begin{gathered}
27 \cdot 0 \\
\text { (foot) }
\end{gathered}
$$

Male and female areas approximately equal in volume and greatly intermixed. Connective tissue septa with young oocytes have penetrated deeply into testis tissue

Predominantly female, only one small male area. Abnormal distribution of gonad-intermixed with gut. Eggs and sperms well developed, very few small eggs

$70 \cdot 0$

(shell)

Predominantly female. Very abnormal with irregular lobed appearance. Ovarian region forms a large excrescence. Two regions quite distinct except at edges where there is some over-growing of female elements by male elements

Predominantly male. Small discrete patches of eggs in centre region which extend to visceral mass. Large oocytes found in testicular tissue 
TABLE III (continued)

Maximum

Specimen Date collected Locality

B I

31. x. 46

2r. x. 47

B2
$(\mathrm{P} 1 . \mathrm{I}$,

figs. 5,7 )

$\mathrm{B}_{3}$

23. viii. $48 \quad$ Isle of May

B 4

6. ix. 48 Isle of May

$3 I \cdot 0$
$($ foot $)$

B 5

B 6 ,

(P1. I,

B 7
6. ix. 48

7. ix. 48

I9. ix. 48

Isle of May
Length of thickness shell or foot

of gonad

(mm)

(2) Patella aspera

Description of gonad based on macroscopic appearance and examination of sections represented. Male and female regions greatly intermixed. Testis tissue appears spent and contains many young oocytes; ovarian tissue seems to be developing

Predominantly male. Testis region consists of a large bilobed mass. A lobe of ovarian tissue lies at the anterior end, a wedge-like extension of which overlies the adjacent testis region. Most eggs seem fully developed though there are some early developmental stages at the ventral surface. Testis region contains fully developed spermatozoa and all other stages in spermatogenesis are well represented

Male and female areas approximately equal in extent. Two welldemarcated areas: testis overlies ovary. Eggs and sperms well developed though developmental stages are present, especially in testicular region. A few isolated large eggs are seen deep in testis tissue. Signs of spawning from ovarian tissue only

Predominantly male. Fairly discrete crescent-shaped area of ovarian tissue which extends throughout thickness of gonad-little intermixing of the two areas. Both contain apparently fully developed genital products as well as developmental stages. Signs

of spawning

Predominantly male. Two large patches of testis separated by ovarian tissue containing several small islands of testicular tissue. Great intermixing in these regions. All areas contain fully developed genital products as well as developmental stages

8.0 Predominantly male. Consists of two large areas of testis separated by a wedge of ovarian tissue running across the shorter axis of the gonad. Some intermixing. Genital products mostly apparently fully developed. Some signs of spawning in both areas

2.5 Predominantly female. Consists of a layer of ovarian tissue covering the visceral mass, with fairly discrete areas of testicular tissue embedded in the more ventral regions. Female area consists mainly of large eggs: some eggs may have been spawned. Much mature spermatozoa and all stages in spermatogenesis. Patches of sperms on connective tissue septa deep in ovarian regions 
Port Erin

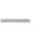

Predominantly male with patches of ovarian tissue which are fairly discrete. Female areas appear more mature than male areas. No sign of spawning

Predominantly (c. $90 \%$ ) male. Dorsal region consists of a loose mass of tissue with a few scattered large eggs and a small amount of relict sperm. Ventral male area very well developed. Much fully
developed sperm and many earlier stages in spermatogenesis. Dorsal regions of gonad appear spent (both male and female areas)

Predominantly male with a few areas of fairly discrete ovarian tissue. Little intermixing. Testis appears almost spent. Ovary consists of a few medium-sized eggs and many small oocytes-may be an early developmental stage

Predominantly male. Great intermixing of ovary and testis, though there is fairly distinct demarcation between them in the regions where they adjoin. Ovary and testis extend from surface to base of gonad and both appear fully developed; some spawning seems to have taken place from both ovary and testis

Not available for histological examination. Gonad obviously very abnormal and predominantly male

Predominantly male. A continuous skin of male tissue overlying basal eggs. Testis appears to be developing; eggs seem mostly mature. Very little intermixing. Eggs visible on macroscopic examination of gonad only at the edges

Predominantly male. Consists of many scattered islands of ovarian tissue lying on ventral surface of a mass of testis tissue. These islands are fairly discrete and some penetrate entire thickness of gonad and reach visceral mass. Both eggs and sperms seem fully developed and there appears to have been some spawning

Predominantly male. Fairly discrete small islands of ovarian tissue consisting of large eggs are scattered throughout the gonad. A few rediae of Cercaria patellae are present: testis tissue in which they lie looks quite normal. Male areas less well developed than female areas

Predominantly male with female area at anterior end. Both regions contain fully developed genital products, though both are almost spent. A few large eggs can be seen along dorsal margin of gonad. Young oocytes are found in fair numbers in the testis tissue 


\section{TABLE III (continued)}

\begin{tabular}{|c|c|c|c|c|}
\hline Specimen & Date collected & Locality & $\begin{array}{l}\text { Length of } \\
\text { shell or foot } \\
\quad(\mathrm{mm})\end{array}$ & $\begin{array}{c}\text { Maximum } \\
\text { thickness } \\
\text { of gonad } \\
\text { (mm) }\end{array}$ \\
\hline $\begin{array}{l}\text { B I7 } \\
\text { (Pl. I, } \\
\text { fig. 9) }\end{array}$ & I7. vi. 47 & Plymouth & $\begin{array}{c}39 \cdot 0 \\
\text { (foot) }\end{array}$ & $I \cdot 6$ \\
\hline $\begin{array}{l}\text { B 18 } \\
\text { (P1. I, } \\
\text { fig. 8) }\end{array}$ & 30. x. 47 & Plymouth & $\begin{array}{c}30 \cdot 0 \\
\text { (foot) }\end{array}$ & $6 \cdot 0$ \\
\hline B I9 & 3. xi. 47 & Plymouth & - & - \\
\hline B 20 & 8. v. 49 & Plymouth & $\begin{array}{c}50 \cdot 0 \\
(\text { shell) }\end{array}$ & $2 \cdot 5$ \\
\hline $\begin{array}{l}\text { B 21 } \\
\text { (Pl. I, } \\
\text { fig. 3) }\end{array}$ & 3. iii. 49 & Plymouth & $\begin{array}{c}35^{\circ} 0 \\
\text { (foot) }\end{array}$ & $4 \cdot 0$ \\
\hline B 22 & 28. vi. 49 & Plymouth & - & 一 \\
\hline B 23 & I9. viii. 47 & Trevone & 一 & - \\
\hline B 24 & 2. ix. 47 & Trevone & 一 & $4 \cdot 0$ \\
\hline
\end{tabular}

Description of gonad based on macroscopic appearance and examination of sections

Predominantly female. Very abnormal in microscopic appearance. Heavily parasitized with rediae of Cercaria patellae. Some large eggs and apparently fully developed sperms are present in isolated patches and are completely intermixed. Some eggs appear to be degenerating

Predominantly female with a skin of testis tissue over most of ventral surface. Eggs and sperms seem fully developed and there has been some spawning. A large cyst of Ophryocotyle sp. is present near centre of ventral region of gonad and in this area the greatest intermixing occurs. Although it lies mainly in the ovarian tissue, there is a large cap of testis tissue covering its ventral surface

Not available for histological examination

Predominantly male. Patches of large eggs present, many of which inter-communicate along dorsal surface of gonad. Both testicular and ovarian regions appear mature. Dorsal region of testicular area almost spent

Predominantly female. Large island of testicular tissue in central region of gonad. This lies in a hollow in the ovarian tissue and does not penetrate as far as dorsal surface of gonad. Great intermixing of male and female tissues at edges. Testicular tissue penetrates deeply into surrounding ovarian region. Few small oocytes

Not available for histological examination

Not available for histological examination

Predominantly female. Eggs and sperms appear mature and show some intermixing

(3) Patella depressa

Predominantly male. Ovarian tissue forms a thin skin on the ventra surface-does not penetrate very deeply into thickness of gonad. Eggs large in size, look somewhat abnormal and are separated by a network of tissue in which spermatogenesis is proceeding - a few fully formed sperms. Male areas less mature than female areas 


\section{REFERENCES}

BACcI, G., 1947. L'inversione del sesso ed il ciclo stagionale della gonade in Patella coerulea L. Pubbl. Staz. zool. Napoli, Vol. 21, pp. 183-217.

CoE, W. R., I943. Sexual differentiation in mollusks, I. Pelecypods. Quart. Rev. Biol., Vol. I8, pp. 154-64.

- 1944. Sexual differentiation in mollusks, II. Gastropods, Amphineurans, Scaphopods and Cephalopods. Quart. Rev. Biol., Vol. 19, pp. 85-97.

- 1945. Development of the reproductive system and variations in sexuality in Pecten and other pelecypod mollusks. Trans. Conn. Acad. Arts Sci., Vol. 36, pp. $673-700$.

DodD, J. M., I956. Artificial fertilisation, larval development and metamorphosis in Patella vulgata L. and Patella coerulea L. Pubbl. Staz. zool. Napoli (in the Press).

Gemmill, J. F., I896. On some cases of hermaphroditism in the limpet (Patella) with observations regarding the influence of nutrition on sex in the limpet. Anat. Anz., Bd. I2, pp. 392-95.

Montalenti, G., I950. Evoluzione della sessualità. Acad. Naz. dei Linc., Vol. 22, pp. 80-103.

Montalenti, G. \& Bacci, G., I95I. Osservazioni e ipotesi sulla determinazione del sesso negli ermafroditi. Sci. genet., Vol. 4, pp. 5-I2.

Orton, J. H., I920. Sex-phenomena in the common limpet (Patella vulgata). Nature, Lond., Vol. I04, p. 373.

- 1928. Observations on Patella vulgata. Part I. Sex-phenomena, breeding and shell-growth. F. mar. biol. Ass. U.K., Vol. I5, pp. 85I-62.

Orton, J. H., Southward, A. J. \& DodD, J. M., I956. Studies on the biology of limpets. Part II. The breeding of Patella vulgata L. in Britain. F. mar. biol. Ass. U.K., Vol. 35, pp. I49-76.

PelseneER, P., I926. La proportion relative des sexes chez les animaux et particulièrement chez les mollusques. Mém. Acad. R. Belg. Cl. Sci., T. I8, pp. I258.

ReEs, F. G., I934. Cercaria patellae Lebour, I9I I, and its effect on the digestive glands and gonads of Patella vulgata. Proc. zool. Soc. Lond., Vol. 45, pp. 45-53.

Smith, F. G. W., I935. The development of Patella vulgata. Phil. Trans. B, No. 520, Vol. 225, pp. 95-125. 


\section{EXPLANATION OF PLATE I}

$P$. aspera and $P$. vulgata: morphology and histology of hermaphrodite gonads.

Fig. I. P. aspera; specimen B6. Approx. natural size. Gonad and visceral mass freed from foot and suspended from it to show ventral surface of gonad. Testicular areas white, ovarian areas black.

Fig. 2. P. aspera; specimen B I2. Approx. natural size. Gonad and visceral mass freed from foot and the latter deflected forward to show ventral surface of gonad. Testicular areas white, ovarian areas black. Note abnormal appearance of gonad.

Fig. 3. P. aspera; specimen B2I. Approx. natural size. Arrangement of parts similar to fig. I. Note discrete island of testicular tissue.

Figs. 4-9 inclusive. T.S. hermaphrodite gonads. Plane of section parallel to dorso-ventral axis.

Fig. 4. P. aspera; specimen BI4. $\times$ I0.

Fig. 5. P. aspera; specimen $\mathrm{B} 2 . \times$ I0.

Fig. 6. P. vulgata; specimen $A_{5} . \times 16$. Note large oocytes in seminiferous tubule.

Fig. 7. P. aspera; specimen $\mathrm{B}_{2} . \times \mathrm{I} 25$. High-power view of region between male and female areas; see fig. 5. Note part of large oocyte at lower edge, isolated groups of spermatozoa, young oocytes and neuter tissue.

Fig. 8. P. aspera; specimen B $18 . \times 25$. Hermaphroditism associated with parasitization. Note that tissue in immediate neighbourhood of cyst of Ophryocotyle is either testicular or neuter.

Fig. 9. P. aspera; specimen $\mathrm{B} 17 . \times 32$. Hermaphroditism associated with parasitization. Note grossly abnormal appearance of gonad and presence of isolated oocytes, patches of testicular tissue and rediae of Cercaria patellae. 



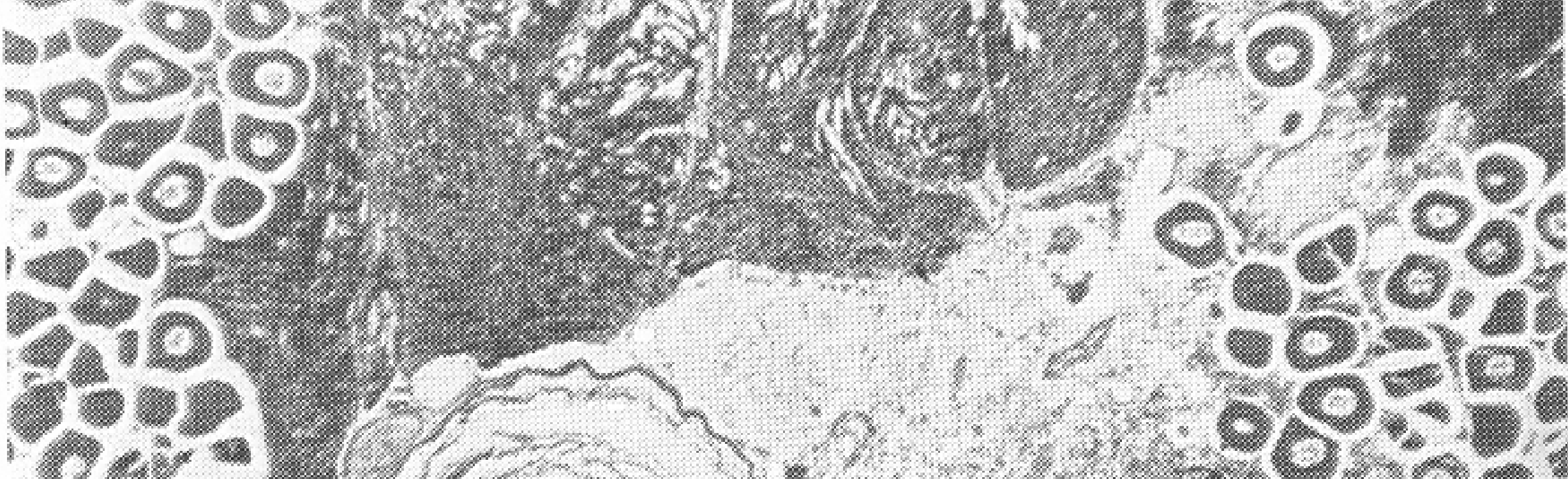

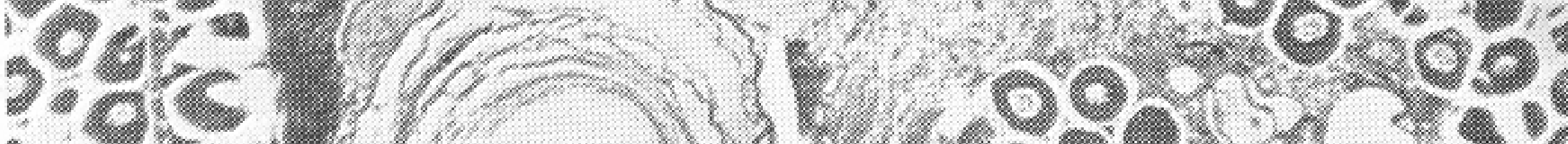
10 y Ja 280.0 88.42 . วos

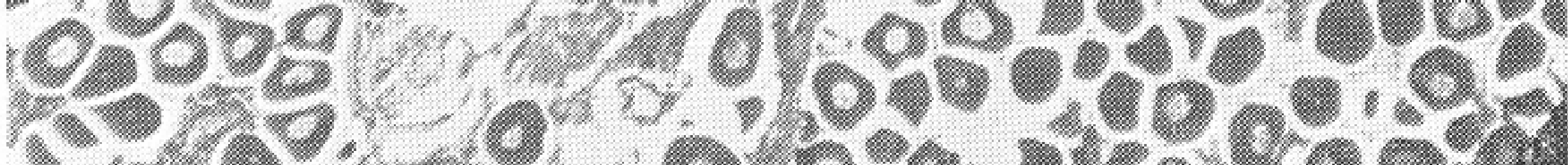

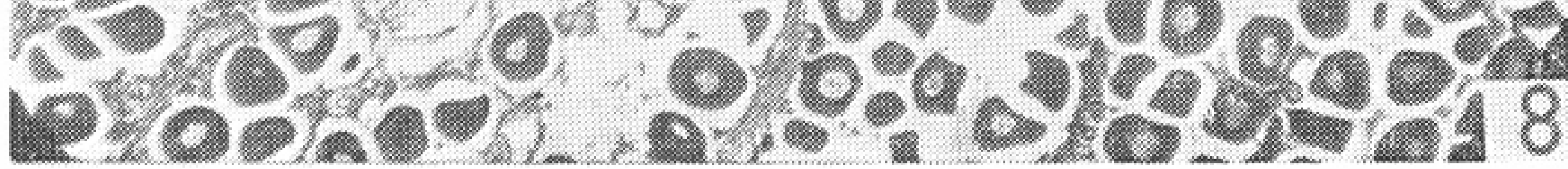

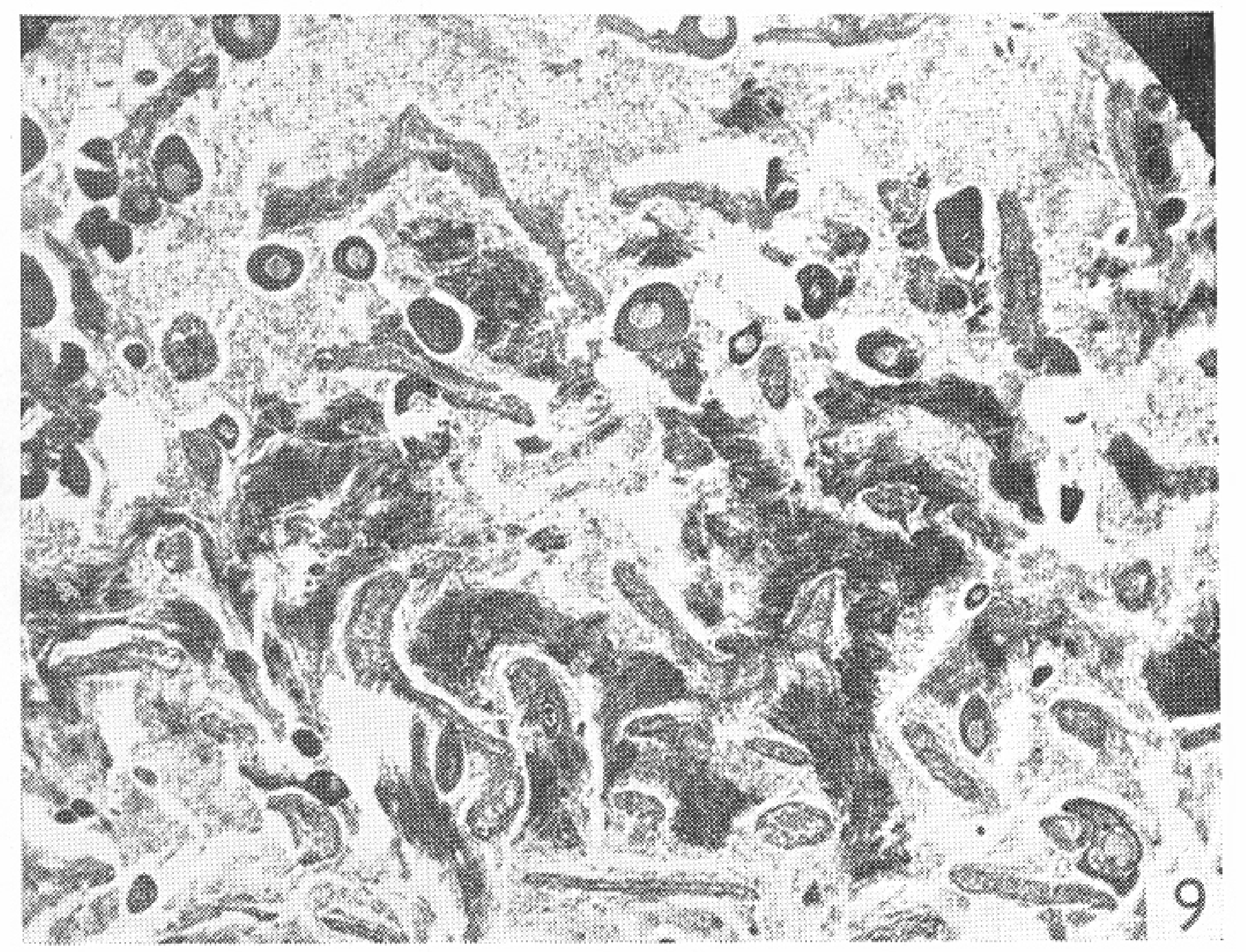

(Facing p. 340) 